\title{
The Effect of Self-Selected Topic and Checklist-based Peer Feedback on Indonesian EFL Students' Writing Ability
}

\author{
Wahyu Diny Sujannah ${ }^{1, *} \&$ Bambang Yudi Cahyono ${ }^{1}$ \\ ${ }^{1}$ English Department, Universitas Negeri Malang, East Java, Indonesia \\ *Correspondence: English Department, Universitas Negeri Malang, East Java, Indonesia. Tel. 62-341-551-334. \\ E-mail: wahyudiny22@gmail.com
}

Received: April 13, 2017

Accepted: May 17, 2017 Online Published: June 25, 2017

doi:10.5430/ijelt.v4n2p1

URL: https://doi.org/10.5430/ijelt.v4n2p1

\begin{abstract}
It has been known that the use of self-selected topic enhances students' writing achievement. It is also known that peer feedback helps improve students' writing achievement. However, research investigating self-selected topic in combination with peer feedback is a rare undertaking. Therefore, this study aimed to investigate the effect of self-selected topic and checklist-based peer feedback on the writing ability of students of English as a foreign language (EFL). This study involved 68 eleven-grade students of Multimedia Program of a Vocational High School at Malang, a city in the Province of East Java, Indonesia. Two intact classes assigned to be experimental and control groups. The experimental group received treatment of self-selected topic and checklist-based peer feedback, while the control group did not. Pre-test and post-test were administered in the form of writing tests to both groups and the results of those tests were analyzed by using independent sample t-Test to know the effect of the treatment. The results showed that the students taught to write with self-selected topic and checklist-based peer feedback outperformed those taught without using self-selected topic and checklist-based peer feedback. Accordingly, it is recommended that English teachers consider assigning the students to write a topic of their own and using checklist-based peer feedback.
\end{abstract}

Keywords: checklist-based peer feedback, EFL students, self-selected topic, writing ability

\section{Introduction}

In our experience in teaching writing, it was not easy to enable English-as-a-foreign-language (EFL) students to write well. When we assigned a particular topic such as "the Use of Technology in the Teaching of English" or "Should Accelerated Learning be Applied in Schools," they could not develop their ideas appropriately. In addition, the students' writing contained errors in vocabulary, grammar, and mechanics (e.g., spelling and punctuation). Our impression on the students' writing reflected students' common difficulties as reported by Al Badi (2015). Al Badi found that the students' difficulties in writing include how to develop ideas on the assigned topics, how to use language correctly, and how to express their own voice. We thought that it was a commonplace to assign the students to write about topics that we determined, not the one that they selected. Our practice in assigning a topic of our interest to the students was opposed by Li (2012). Students in Li's study were able to determine topics of their own for their writing. Thus, as Li stated, it is wrong to think that "EFL students feel incapable of deciding about what they would like to write" (p. 41).

When given choices, students are likely to write preferred topics or things they knew best. In other words, they can write with confidence when they are familiar with the topics. Research regarding the role of topic familiarity in writing (e.g., Ji, 2011; Bonyadi \& Zainalpur, 2014) indicates that students write better if they are familiar with the topics. Therefore, we believed that the application of self-selected topic could improve the students' writing achievement. However, giving freedom on topic selection might partially solve the students' difficulties in writing, especially dealing with the contents of the students' writing. Therefore, in the present study, we intended to apply self-selected topic in combination with checklist-based peer feedback. Peer feedback is chosen as an additional variable because the application of peer feedback improved the quality of the students' writing (e.g., Villamil \& Guerrero, 1998; Cahyono \& Amrina, 2016). 


\section{Literature Review}

\subsection{Self-Selected Topic}

Self-selected topic and peer feedback as two separate variables have been investigated in a lot of research studies. Self-selected topic is a topic selected freely by the students. The application of self-selected topic in writing has a number of advantages. First, when the students are familiar with a topic and have sufficient background knowledge about the topic, they can organize and develop their ideas well. A study conducted by Lubold, Forbes, and Steveson (2016) showed that self-selected topic had a significant effect on the students' writing fluency. They explained that the improvement in writing fluency was the result of the students' prior knowledge of the topic they have selected. Second, compared to the teacher-assigned topic which limits students' freedom, self-selected topic allows the students to explore and express their ideas and thoughts freely. Li (2012) argues that self-selection of topics is one of the important elements in self-regulated learning. This is because self-selection of topics entails the idea about "learners' understanding (of) their own ability, interests, and beliefs in the possibility of reaching their goals" (p. 44). As a result, the students can get better achievement in their writing products. Finally, in general, self-selected topic enhances the quality of their students' writing products (Shippen, Houchins, Puckett et al., 2007).

From the points of view of the students, self-selected topic has been perceived positively. Wolf (2013) conducted a study analyzing perceptions of EFL students on textbook-assigned and self-selected discussion topics. The participants were 101 second-year students of Tourism Department of Tokyo University. They were asked to fill a series of 5-point Likert-scale questionnaire used in the study and to write an argumentative essay. The findings revealed that in discussing their own topic, the students had significantly higher perceptions of interest and knowledge related to their topic.

\subsection{Peer Feedback}

Peer feedback is defined as a strategy in which the students share their writing to each other, find the errors, and give feedback to improve the quality of their classmates' work. In the end, they can revise their writing products based on their classmates' feedback before being submitted. Hyland (2003) explained that peer feedback provision usually comprises "assigning students to groups of two, three, or four who exchange completed first drafts and give comments on each other's work before they revise them" (p. 200). Conducting peer feedback offers many advantages. It can increase students' activeness and participation during the process of teaching and learning since the students will be the ones who correct and give feedback to their classmates' work. Thus, it will become student-centered learning. In addition, as shown in Villamil and Guerrero's (1998) research, points of feedback contributed to the final version of the students' writing. Furthermore, students can learn from their classmates' work on how to focus on the topic, organize the idea, develop it into paragraphs, and many more. By doing this, they can improve the quality of their writing product. Besides, peer feedback offers "more flexible and non-coercive decisions about whether the learners should adopt their peers' suggestions" (Lin \& Chien, 2009, pp. 79-80). The students given feedback do not have to use the feedback if they think that it cannot improve the quality of their writing product. Finally, it can also broaden their knowledge. Since every student may have a different topic to deal with, they can get new insights after reading their classmates' work.

Students have a positive perception toward peer feedback. Altstaedter and Doolittle (2014) carried out a study on examining students' perceptions of peer feedback. The researched involved sixty-five undergraduate students enrolled in four intact Intermediate Spanish college classes at a major university in the southeastern United States. After experiencing peer feedback, they were required to fill a 7-point Likert-scale questionnaire. The findings revealed that students had positive perceptions of receiving written feedback. Besides perceiving peer feedback positively, students also like peer feedback more than teacher feedback. This is because teachers' negative comments toward students' writing products can make them down and lost their confidence to write. In addition, as shown in the results of research conducted by Jacobs, Curtis, Braine and Huang (1998), many of the students preferred peer feedback as peers provide more ideas than teacher feedback.

Based on the issues presented above, this study investigated the effect of self-selected topic and checklist-based peer feedback on Indonesian EFL students' writing ability. The questions to be addressed in this study are as follows:

1. Do the students taught by using self-selected topic and checklist-based peer feedback have better writing ability than those taught without using self-selected topic and checklist-based peer feedback?

2. What is the topic most-frequently selected by Indonesian EFL students? 


\section{Method}

\subsection{Research Design}

The present study used quasi-experimental research as the design. It aimed to investigate the effect of self-selected topic and checklist-based peer feedback on Indonesian EFL students' writing ability.

\subsection{Participants}

This study involved 68 eleven-grade students of Multimedia Program at Vocational High School in Malang, Indonesia. They were taken from two intact classes in which Multimedia 1 and Multimedia 2 classes were assigned as the experimental and control groups, respectively. Each class consisted of 34 students. They used the same English textbook and had equal number of English sessions.

\subsection{Checklist Development}

Before developing the checklist, the researchers conducted literature review of the important writing aspects that needed to be given attention. According to Jacobs, Zinkraf, Wormuth et al. (1981), there are five writing aspects, namely content, organization, vocabulary, language use, and mechanics. Meanwhile, Oshima and Hogue (2007) identified five aspects which include format, punctuation and mechanics, content, organization, and grammar and sentence structure. In developing the checklist, we were inspired by the EFL Composition Profile proposed by Jacobs et al. (1981) and included the writing aspects in the checklist. In each writing aspect, we put some statements related to the aspect that should be filled based on the quality of the students' writing products. For this purpose, we used Cahyono and Amrina's (2016) Guideline for Peer Feedback and Oshima and Hogue's (2007) Peer-Editing Worksheet as references. In the content aspect, the statements were related to the introduction, topic sentences, and supporting details of the text. In the organization aspect, the statements consisted of the coherence, cohesion, and generic structure of the text. In the vocabulary aspect, the statements dealt with the variety, relevance, and appropriateness of the diction. In the language use aspect, the statements focussed on the tenses, singular and plural markers, transitional markers, and part of speech. In the mechanics aspect, the statements addressed the capitalization, punctuation, and spelling.

Then, we provided three options to the students to fill out the checklist, namely 'yes,' 'adequate,' and 'no.' If they thought that their classmates' work had already met the statements, they could tick the 'yes' column, and the opposite applies to the 'no' column. We give 'adequate' option so that they could tick it when they thought that their classmates' work has not really fit the statements. In the end, we gave a column for "comments and suggestions" on each writing aspect so that the students could give constructive feedback to help improve the quality of their classmates' writing products. In the administration, the checklist was written in the students' first language (Indonesian) to enable them to understand the contents easier. The checklist for the peer feedback is included in Appendix A.

\subsection{Instrument Validation}

The writing prompts and peer feedback checklist were validated by two experts in English Language Teaching who are also Professors in the English Department of Universitas Negeri Malang, Indonesia. The expert validation was aimed to know that the instruments could be used to collect the data representing the students' writing ability.

\subsection{Data Collection}

In the beginning of the study, the experimental and control groups were given a pre-test. It was a writing test in which the students had to compose a report text containing a minimum of 200 words within 60 minutes. The theme for the pre-test was Public Places. After taking pre-test, the experimental group received treatment of self-selected topic and checklist-based peer feedback, while the control group did not. The experimental group was asked to determine their topic in writing report texts. After choosing the topic and developing it into paragraphs, they were divided into groups and conducted peer feedback. In doing the peer feedback, they were given a peer feedback checklist to be used as a basis to do peer feedback. After the treatment was completely given, both groups took the post-test. The post-test was the same as the pre-test in which they were also asked to compose a minimum of 200 -word report text in 60 minutes. The theme for the pre-test was Electronic Tools.

\subsection{Data Analysis}

To improve the reliability, the results of the pre-test and post-test were assessed by two raters (inter-rater reliability) by using the scoring rubric adapted from EFL Composition Profile proposed by Jacobs et al. (1981). The raters had to give analytical scores to five writing aspects, namely content (30), organization (20), vocabulary (20), language use (20), and mechanics (5). The average scores from Rater 1 and Rater 2 were computed to get the students' final 
scores of students' pre-test and post-test shown in Appendix B.

The results of the students' pre-test were analyzed by using independent sample $t$-test to find out the homogeneity of the groups in terms of writing achievement before treatment. In the same vein, the results of the students' post-test were also analyzed by using independent sample t-test to find out whether or not the treatment had impact on the students' writing ability.

The obtained Pearson coefficients of both the experimental group and control group in the pre-test from both raters were .828 and .743 , respectively. In contrast, the obtained Pearson coefficients of both the experimental group and control group in the post-test from both raters were .889 and .875 , respectively. In addition, the obtained significant alpha of both groups in the pre-test and post-test for both raters were .000 . This means that the scores from the two raters had high inter-rater reliability.

\section{Results}

\subsection{Fulfillment of the Statistical Assumptions}

The fulfillment of the statistical assumptions was done to test the homogeneity and normality of the data collected. In the homogeneity testing, the results showed that the observed significant levels for Levene's test of both the experimental and control groups in the pre-test and the post-test were .775 and .558 , respectively. In other words, the observed significant levels were greater than $.05(.775 \geq .05$ and $.558 \geq .05)$, meaning that the two groups were homogeneous. In the normality testing, the results showed that the observed significant levels for One-Sample Kolmogorov-Smirnov test of the experimental group in the pre-test and the post-test were .495 and .293 , respectively. Thus, the obtained significant levels were greater than $.05(.495 \geq .05$ and $.623 \geq .05)$. Like the experimental group, the obtained significant levels for One-Sample Kolmogorov-Smirnov test of the control group in the pre-test and the post-test were .623 and .906 , respectively. It meant that the observed significant levels were greater than .05 (.623 $\geq .05$ and $.906 \geq .05$ ). Those results showed that the data taken from the samples were normally distributed.

\subsection{Results of the Pre-Test and Post Test of the Experimental and Control Groups}

The results of the pre-test and post-test of the experimental and control group were shown below.

\subsubsection{Results of the Pre-Test of the Experimental and Control Groups}

The results of the pre-test of the experimental and control groups are shown in Table 1.

Table 1. Descriptive Statistics of the Pre-Test Scores of the Experimental and Control Groups

\begin{tabular}{ccccccc}
\hline Group & $\mathrm{N}$ & Minimum & Maximum & Mean & Variance & SD \\
\hline Experimental & 34 & 51 & 82 & 64.88 & 7.65 & 58.5 \\
Control & 34 & 56 & 78 & 66.53 & 6.20 & 38.4 \\
\hline
\end{tabular}

Table 1 shows that the mean of the pre-test score of the experimental group differs from that of the control group. The mean of the experimental group was 64.88 , while the mean of the control group was 66.53 . The difference between the two means was 1.65. It means that the mean of the control group was greater than that of the experimental group. To know whether the difference was significant or not, an independent sample t-Test was conducted. The result is shown in Table 2.

Table 2. Results of Independent Sample $t$-Test of the Pre-Test Scores of the Experimental and Control Groups

\begin{tabular}{|c|c|c|c|c|c|c|c|}
\hline & \multicolumn{7}{|c|}{$t$-Test for Equality of Means } \\
\hline & \multirow{2}{*}{$\mathrm{T}$} & \multirow{2}{*}{$\mathrm{df}$} & \multirow{2}{*}{$\begin{array}{c}\text { Sig. } \\
(2 \text {-tailed })\end{array}$} & \multirow{2}{*}{$\begin{array}{c}\text { Mean } \\
\text { Difference }\end{array}$} & \multirow{2}{*}{$\begin{array}{l}\text { Std. Error } \\
\text { Difference }\end{array}$} & \multicolumn{2}{|c|}{$\begin{array}{l}95 \% \text { Confidence Interval } \\
\text { of the Difference }\end{array}$} \\
\hline & & & & & & Lower & Upper \\
\hline Equal variances assumed & -.976 & 66 & .333 & -1.64706 & 1.68827 & -5.01781 & 1.72369 \\
\hline $\begin{array}{l}\text { Equal variances not } \\
\text { assumed }\end{array}$ & -.976 & 63.280 & .333 & -1.64706 & 1.68827 & -5.01781 & 1.72369 \\
\hline
\end{tabular}


As shown in Table 2, there was a significant difference between the means of the pretest scores of the experimental and control groups. The observed significant level of both groups was .33. In other words, the observed significant level was greater than $.05(.33 \geq .05)$, meaning that the null hypothesis could not be rejected.

\subsubsection{Results of the Post-Test of the Experimental and Control Groups}

The results of the post-test of the experimental and control groups are shown in Table 3.

Table 3. Descriptive Statistics of the Post-Test Scores of the Experimental and Control Groups

\begin{tabular}{ccccccc}
\hline Group & $\mathrm{N}$ & Minimum & Maximum & Mean & Variance & SD \\
\hline Experimental & 34 & 66 & 93 & 82.03 & 6.85 & 46.85 \\
Control & 34 & 65 & 86 & 75.24 & 5.98 & 35.81 \\
\hline
\end{tabular}

Table 3 shows that there was a difference between the post-test scores of the experimental group and the control group after the treatment. It demonstrated that the mean of the experimental group was 82.03 , while the mean of the control group was 75.24. The difference between the two means was 6.79. This indicates that the mean of the experimental group was higher than the mean of the control group. Since the result of the independent sample $t$-test of the pre-test scores revealed that there was no significant difference, an independent sample $t$-test could be conducted again to know whether there was a significant difference in the post-test scores of the two groups. The result can be seen in Table 4 .

Table 4. Results of Independent Sample t-Test of the Post-Test Scores of the Experimental and Control Groups

\begin{tabular}{|c|c|c|c|c|c|c|c|}
\hline & \multicolumn{7}{|c|}{$\mathrm{t}$-Test for Equality of Means } \\
\hline & \multirow[t]{2}{*}{$\mathrm{T}$} & \multirow[t]{2}{*}{$\mathrm{df}$} & \multirow{2}{*}{$\begin{array}{c}\text { Sig. } \\
\text { (2-tailed) }\end{array}$} & \multirow{2}{*}{$\begin{array}{c}\text { Mean } \\
\text { Difference }\end{array}$} & \multirow{2}{*}{$\begin{array}{l}\text { Std. Error } \\
\text { Difference }\end{array}$} & \multicolumn{2}{|c|}{$\begin{array}{c}95 \% \text { Confidence Interval } \\
\text { of the Difference }\end{array}$} \\
\hline & & & & & & Lower & Upper \\
\hline $\begin{array}{l}\text { Equal variances } \\
\text { assumed }\end{array}$ & 4.341 & 66 & .000 & 6.79412 & 1.56502 & 3.66946 & 9.91877 \\
\hline $\begin{array}{l}\text { Equal variances } \\
\text { not assumed }\end{array}$ & 4.341 & 64.730 & .000 & 6.79412 & 1.56502 & 3.66832 & 9.91992 \\
\hline
\end{tabular}

Table 4 shows that the difference of the means of the two groups was significant. The observed significant level of both groups was .000 . In other words, the observed significant level was lower than $.05(.00 \geq .05)$, meaning that the null hypothesis could be rejected. The mean of the experimental group was significantly higher than the mean of the control group. Thus, the students who were taught by using self-selected topic and checklist-based peer feedback had better ability in writing than those taught without using self-selected topic and peer feedback.

In addition to the result of comparison of the experimental and control groups, the present study also revealed the topics most-frequently selected by the students in the experimental group. The list of topics selected by the students in the experimental group is shown in Table 5.

Table 5. List of Topics Selected by the Students in the Experimental Group ( $\mathrm{N}=34)$

\begin{tabular}{clcc}
\hline No & Topic & $\mathrm{f}$ & $\%$ \\
\hline 1 & Gadgets & 10 & $29 \%$ \\
2 & Electronic & 8 & $23 \%$ \\
& Tools & & \\
3 & Social Media & 6 & $18 \%$ \\
4 & Technologies & 5 & $15 \%$ \\
5 & Public Places & 3 & $9 \%$ \\
6 & Animals & 2 & $6 \%$ \\
\hline
\end{tabular}


Table 5 shows that the most-frequently selected topic by Indonesian EFL Students was gadgets (e.g., smartphone and tablet). This topic was selected by $10(29 \%)$ out of 34 students in the experimental group. The next topics were electronic tools (e.g., television and computer) which was selected by 8 students (23\%), social media (e.g., social networking site and blog) which was selected by 6 students (18\%), technologies (e.g., Internet and car) which was selected by 5 students (15\%), and public places (e.g., school and hospital) which was selected by 3 students (9\%). It also shows that the topic least-frequently selected by Indonesian EFL Students was animals (i.e., elephant and cat) which was selected by 2 students $(6 \%)$.

\section{Discussion}

The results of this study showed that the use of self-selected topic and checklist-based peer feedback could improve the students' writing ability. With regard to self-selected topic in particular, Li (2012) stated that when given choices, students can "regain the chance to practice the critical thinking and cope with the multiple answers for controversial issues" (p. 54). Moreover, they could also release their anxiety and raise their confidence. As they could write whatever they liked, their creativity and way of thinking would not be limited. As stated by Bonyadi and Zainalpur (2014), self-selected topics "let them think freely and experience a sense of democratic classroom atmosphere" (p. 369). By giving freedom to select their own topic, they would learn and enjoy more in the writing activity. Furthermore, because their writing product could be corrected and revised first before submitting it to the teachers, they believed that they could get high scores. It strengthened the results of Yastiba and Yastiba's (2015) study unveiling that peer feedback in writing classes decreased students' writing anxiety, increased their confidence, and improved their writing by collaborating with and learning from each other.

On top of that, self-selected topic could broaden the students' knowledge. Each student might have a different topic to deal with. As a result, they could get new insights after reading their classmates' work. The findings of Dickinson's (2014) study revealed that the students enjoyed doing the writing activity and would like to do more in-class writing in the future. $\mathrm{Li}$ (2012) also argued that by giving them a chance to choose their own topic, they would feel "motivated in learning and be empowered in both personal and professional development" (p. 55).

Analysis of the students' works in the post-test also showed that the students gave more detailed information and facts. They also elaborated and supported their ideas clearly. These might suggest that they had much knowledge about the given topic and how to develop their ideas into a written text. They might have learned how to organize, elaborate, develop, and support their ideas by giving detailed information or facts from their classmates' work during peer feedback activity. This study is relevant to the study conducted by Ji (2011) who found that students wrote better in the essay with the more focussed topic, compared to a general one. Ji mentioned that students could write better in a more focussed topic as they were familiar with the topic.

Additionally, they could also know aspects that need to be improved to have better quality of writing. They knew their strengths and weaknesses in writing since they could compare their work to their classmates' work. As stated by Maarof, Yamat, and Li (2011), "learners can learn more about writing and revision by reading each other's drafts critically and their awareness of what makes writing successful and effective can be enhanced" (p. 30). The results of this study confirmed the findings of Sukumaran and Dass (2014) that peer feedback helped learners to recognize their strengths and flaws in writing. Similarly, the results of Bonyadi and Zainalpur's (2014) study proved that when the students were granted with the choice of selecting their own topic for writing, they could support, organize, and classify their main idea. Therefore, they would be able to explore their self-selected topic and come up with a good writing.

Moreover, the students began to use relevant and easy-to-understand vocabulary. Since they had a right to select their own topic, they tended to write anything they knew best. As a consequence, they had sufficient background knowledge about the topic. Ferreira (2013) stated that "the students seem to express themselves with a larger variety of words when asked to write about their own topic" (p. 304). In addition, they might also have read many texts during the peer feedback activity. Since students were given freedom to select their own topic during the treatment, they would have different topics. By reading and analyzing their classmates' works of varied topics, they could learn new vocabularies. Although at first they could not understand the meaning of the words, they could ask their classmates and looked up their dictionary during the peer feedback activity. Hence, it could improve their mastery of vocabulary. It strengthened the results of Altstaedter and Doolittle's (2014) study revealing that peer feedback improved vocabulary richness. In the same vein, the findings of Ghanbari, Karampourchangi, and Shamsaddini (2015) unveiled that peer feedback process improved the students' vocabulary and punctuation knowledge.

Furthermore, the students also improved their grammatical knowledge. They rarely made mistakes to add "-s or -es" 
after the singular subject. Besides, they also began to use conjunction to connect the sentences. This might happen after conducting peer feedback as discussion about the results of the peer feedback in terms of the weaknesses and problems in their writing was always held. In this case, the most concerned aspect was grammar. By doing this, they gradually started to be aware of their mistakes. It reminded them not to repeat the same mistakes in the next writing. It was also proved by a qualitative case study carried out by Shulin (2013). Shulin's study showed that peer feedback was helpful to make the students aware of the common errors in their writing, learn from their peer's writing, raise the audience's awareness, enhance their own writing quality, stir self-reflections, and promote interest and motivation in second language writing. Additionally, the students could develop their critical thinking skills. Shulin (2013) argued that peer feedback can make the students "identify the basic errors in their peers' essays" and "remind themselves about not committing similar mistakes" (p. 76) in their own writing.

\section{Conclusion}

The result of this study unveiled that the students taught by using self-selected topic and checklist-based peer feedback had better writing ability than those taught without using self-selected topic and checklist-based peer feedback. The result of this study is consistent with the findings of previous research studies which examined separate application of self-selected topic and peer feedback. This means that more opportunities are provided for endeavors in improving the students' writing ability, namely by applying either self-selected topic, peer feedback provision, or combination of self-selected topic and checklist-based peer feedback as used in this study. Apart from the main result, this study also found topics preferred by the students of Vocational High Schools involved in this study. The list of the topics might be useful for teachers of EFL writing in other secondary schools, be it in Indonesia or in other in other EFL countries. Some recommendations are directed to English teachers and future researchers working with EFL writing in secondary schools or in the university level. For English teachers, it is recommended that they need to consider applying and implementing the combined strategies in the teaching of EFL writing. For further researchers, it is suggested that they investigate the effect of self-selected topic and online peer feedback in different text types and language skills.

\section{References}

Al Badi, I. A. H. (2015). Academic writing difficulties of ESL learners. In The WEI International Academic Conference, Barcelona, Spain: West East Institute. Retrieved from https://www.westeastinstitute.com/ proceedings/2015-barcelona-presentations/

Altstaedter, L. L., \& Doolittle, P. (2014). Students' perceptions of peer feedback. Argentinian Journal of Applied Linguistics, 2(2), 60-76.

Bonyadi, A., \& Zeinalpur, S. (2014). Perceptions of students towards self-selected and teacher-assigned topics in EFL writing. Procedia - Social and Behavioral Sciences, 98, 385-391. https://doi.org/10.1016/j.sbspro.2014.03.430

Cahyono, B. Y., \& Amrina, R. (2016). Peer-feedback, self-correction, and writing proficiency of Indonesian EFL students. Arab World English Journal, 7(1), 78-193.

Dickinson, P. (2014). The effect of topic-selection control on EFL writing fluency. Journal of Niigata University of International and Information Studies, 17, 15-25.

Ferreira, D. (2013). Researching the effects of students' self-selected topics on writing fluency. Ferris Studies, 48, 297-306.

Ghanbari, N., Karampourchangi, A., \& Shamsaddini, M. R. (2015). An exploration of the effect of time pressure and peer feedback on the Iranian EFL students' writing performance. Theory and Practice in Language Studies, 5(11), 2251-2261. https://doi.org/10.17507/tpls.0511.08

Hyland, K. (2003). Second language writing. Cambridge: Cambridge University Press.

Jacobs, G.M., Curtis, A., Braine, G., \& Huang, S. (1998). Feedback on student writing: Taking the middle path. Journal of Second Language Writing, 7(3), 307-317.

Jacobs, H. L., Zinkraf, S. A., Wormuth, D. R., Hartfiel, V. F., \& Hughey, J. B. (1981). Testing ESL composition: A practical approach. Rowley, MA: Newbury House. https://doi.org/10.1016/S1060-3743(98) 90019-4

Ji, X. (2011). Topic effects on writing performance: What do students and their writing tell us? The Journal of Asia TEFL, 8(1), 23-38. 
Li, L.T. (2012). Embracing the diversity: Learning from EFL students' self-selected reading and writing. TESL Reporter Journal, 45(2), 41-62.

Lin, G. H. C., \& Chien, P. S. C. (2009). An investigation into effectiveness of peer feedback. Journal of Applied Foreign Languages Fortune Institute of Technology, 3, 79-87.

Lubold, S. L., Forbes, S., \& Steveson, I. (2016). The effect of topic selection on writing fluency among Japanese high school students. Indonesian Journal of Applied Linguistics, 5(2), 231-241. https://dx.doi.org/10.17509/ ijal.v5i2.1347

Maarof, N., Yamat, H., \& Li, K. L. (2011). Role of teacher, peer and teacher-peer feedback in enhancing ESL students' writing. World Applied Sciences Journal (Innovation and Pedagogy for Lifelong Learning), 15, 29-35.

Oshima, A., \& Hogue, A. (2007). Introduction to academic writing. White Plains, NY: Pearson-Longman.

Shippen, M. E., Houchins, D. E., Puckett, D., \& Ramsey, M. (2007). Preferred writing topics of urban and rural middle school students. Journal of Instructional Psychology, 34(1), 59-66.

Shulin, Y. (2013). EFL teachers' beliefs and practices regarding peer feedback in L2 writing classrooms. Polyglossia, 24, 74-79.

Sukumaran, K., \& Dass, R. (2014). Students' perspectives on the use of peer feedback in an English as a second language writing class. Journal of Interdisciplinary Research in Education (JIRE), 4(1), 27-40.

Villamil, O. S., \& Guerrero, M. C. M. de. (1998). Assessing the impact of peer revision on L2 writing. Applied Linguistics, 19(4), 491-514. https://doi.org/10.1093/applin/19.4.491

Wolf, J. P. (2013). Exploring and contrasting EFL learners' perceptions of textbook-assigned and self-selected discussion topics. Language Teaching Research, 17(1), 49-66. https://doi/abs/10.1177/ 1362168812457535

Yastiba, G. C., \& Yastiba, A. E. (2015). The effect of peer feedback on writing anxiety in Turkish EFL (English as a foreign language) students. Procedia - Social and Behavioral Sciences, 199, 530-538. https://doi.org/10.1016/j.sbspro.2015.07.543 


\section{Appendix A. Peer Feedback Checklist}

\section{PEER FEEDBACK CHECKLIST}

\begin{tabular}{|c|c|c|c|c|c|c|}
\hline \multicolumn{2}{|c|}{ Reviewer: } & Writer: & & & & \\
\hline \multicolumn{7}{|c|}{$\begin{array}{l}\text { Instruction: Read your friends' writing work thoroughly. Give feedback by putting a tick (V) on the following } \\
\text { statements. You may give comments and suggestions to help improve your friends' writing ability. }\end{array}$} \\
\hline No & Components & Indicators & Yes & Adequate & No & $\begin{array}{l}\text { Comments } \\
\text { and } \\
\text { Suggestions }\end{array}$ \\
\hline \multirow{5}{*}{1.} & \multirow{5}{*}{ Content } & $\begin{array}{l}\text { The introduction is effective to lead the readers } \\
\text { to the topic. }\end{array}$ & & & & \\
\hline & & $\begin{array}{l}\text { Each paragraph has a clear and effective topic } \\
\text { sentence. }\end{array}$ & & & & \\
\hline & & $\begin{array}{l}\text { Each topic sentence is relevant to the thesis } \\
\text { statement. }\end{array}$ & & & & \\
\hline & & $\begin{array}{l}\text { Each paragraph contains detailed information } \\
\text { and fact to support the topic sentence. }\end{array}$ & & & & \\
\hline & & $\begin{array}{l}\text { Each supporting detail is clearly and thoroughly } \\
\text { explained. }\end{array}$ & & & & \\
\hline \multirow{5}{*}{2.} & \multirow{5}{*}{ Organization } & $\begin{array}{l}\text { The paragraphs are well-organized and } \\
\text { coherent. }\end{array}$ & & & & \\
\hline & & The sentences are well-connected. & & & & \\
\hline & & The ideas are clearly stated and supported. & & & & \\
\hline & & The ideas are presented in a logical order. & & & & \\
\hline & & $\begin{array}{l}\text { The paragraphs contain clear general } \\
\text { classification and description. }\end{array}$ & & & & \\
\hline \multirow{4}{*}{3.} & \multirow{4}{*}{ Vocabulary } & The vocabularies are varied. & & & & \\
\hline & & The vocabularies are relevant to the topic. & & & & \\
\hline & & $\begin{array}{l}\text { The vocabularies are advanced and } \\
\text { sophisticated. }\end{array}$ & & & & \\
\hline & & The vocabularies are easy to understand. & & & & \\
\hline \multirow{4}{*}{4.} & \multirow{4}{*}{ Language Use } & The sentence uses correct tense. & & & & \\
\hline & & $\begin{array}{l}\text { The singular and plural markers are used } \\
\text { correctly. }\end{array}$ & & & & \\
\hline & & $\begin{array}{l}\text { The conjunctions and connectors are used } \\
\text { correctly. }\end{array}$ & & & & \\
\hline & & $\begin{array}{l}\text { The pronouns, articles, and prepositions are } \\
\text { used correctly. }\end{array}$ & & & & \\
\hline \multirow{4}{*}{5.} & \multirow{4}{*}{ Mechanics } & The main words in the title are capitalized. & & & & \\
\hline & & Each sentence begins with a capital letter. & & & & \\
\hline & & Each sentence ends with a proper punctuation. & & & & \\
\hline & & Each word has correct spelling. & & & & \\
\hline
\end{tabular}




\section{Appendix B. The Pre-Test and Post-Test Scores of the Experimental and Control Groups}

\begin{tabular}{|c|c|c|c|c|c|c|}
\hline \multirow{2}{*}{ No. } & \multicolumn{3}{|c|}{ Experimental Group } & \multicolumn{3}{|c|}{ Control Group } \\
\hline & Name Code & Pre-Test & Post-Test & Name Code & Pre-Test & Post-Test \\
\hline 1. & AW & 63 & 80 & $\mathrm{MF}$ & 68 & 79 \\
\hline 2. & ADS & 51.5 & 72.5 & MNRW & 64 & 74 \\
\hline 3. & ADRA & 69.5 & 85.5 & MFHS & 65 & 72 \\
\hline 4. & AA & 71 & 87 & MDA & 62 & 69 \\
\hline 5. & AMA & 60 & 77 & MRH & 76.5 & 78.5 \\
\hline 6. & AKA & 62.5 & 79.5 & MAA & 77 & 82 \\
\hline 7. & AP & 51 & 69.5 & MAS & 74.5 & 84.5 \\
\hline 8. & $\mathrm{AD}$ & 82 & 82 & MKAI & 78 & 75.5 \\
\hline 9. & AA & 52.5 & 71 & MNR & 72 & 84 \\
\hline 10. & AKD & 65 & 86 & MRR & 72.5 & 81.5 \\
\hline 11. & AS & 63.5 & 81.5 & MNA & 60.5 & 74 \\
\hline 12. & ADW & 66 & 89 & MA & 60.5 & 70.5 \\
\hline 13. & AMP & 66 & 86.5 & $\mathrm{M}$ & 61 & 68.5 \\
\hline 14. & ACLY & 66.5 & 86 & $\mathrm{MNN}$ & 60.5 & 69.5 \\
\hline 15. & ASD & 68 & 86 & NM & 61.5 & 66 \\
\hline 16. & AIWH & 63.5 & 81 & NNA & 61 & 71.5 \\
\hline 17. & AS & 69 & 93 & NGMN & 71.5 & 86 \\
\hline 18. & $\mathrm{AAF}$ & 67 & 85 & NDB & 63 & 74 \\
\hline 19. & ANA & 79 & 81.5 & NJT & 70 & 70 \\
\hline 20. & $\mathrm{BS}$ & 54 & 72 & NI & 67 & 76 \\
\hline 21. & $\mathrm{CP}$ & 65 & 78.5 & $\mathrm{NNF}$ & 61 & 68.5 \\
\hline 22. & $\mathrm{CC}$ & 74 & 92 & NAA & 74 & 74.5 \\
\hline 23. & DIY & 56.5 & 66 & NAW & 65 & 76 \\
\hline 24. & DAAR & 73 & 83 & $\mathrm{NH}$ & 61 & 74.5 \\
\hline 25. & $\mathrm{DA}$ & 70 & 91.5 & NI & 74 & 83.5 \\
\hline 26. & DO & 54 & 75 & PFF & 56 & 65 \\
\hline 27. & DAN & 70.5 & 86 & PNRA & 63.5 & 76 \\
\hline 28. & DAP & 70 & 88 & PA & 69 & 81 \\
\hline 29. & $\mathrm{DA}$ & 51.5 & 71 & QBK & 72 & 82 \\
\hline 30. & DN & 64.5 & 82 & RGP & 67.5 & 78 \\
\hline 31. & DRNP & 66 & 85 & $\mathrm{R}$ & 56.5 & 67 \\
\hline 32. & DFR & 65.5 & 88.5 & $\mathrm{RN}$ & 61 & 67 \\
\hline 33. & ERP & 71.5 & 85.5 & RNN & 62.5 & 75.5 \\
\hline \multirow[t]{3}{*}{34.} & ERF & 63.5 & 85.5 & RMS & 73 & 83.5 \\
\hline & Total & 2206 & 2789 & Total & 2262 & 2558 \\
\hline & Mean & 64.88 & 82.03 & Mean & 66.53 & 75.24 \\
\hline
\end{tabular}

